\title{
FEATURE
}

\section{Full-Time Reference with Part-Time Librarians}

\section{Dealing with Staffing Realities, Meeting UserNeeds}

\section{Valery King and Sara Christensen-Lee}

Valery King (valery.king@oregonstate .edu) is Social Sciences/Humanities and Government Information Librarian at Oregon State University Libraries \& Press, Corvallis, Oregon.

\section{Sara Christensen-Lee}

(sarachristensenlee@gmail.com) is Information Management Specialist at NuScale Power, Corvallis, Oregon.
Reference \& User Services Quarterly, vol. 54, no. 1, pp. 34-43

(c) 2014 American Library Association. All rights reserved.

Permission granted to reproduce for nonprofit, educational use.

Shifting priorities in academic libraries have led to experimentation in methods of keeping a reference desk open for the users who still need in-person, immediate help while at the same time freeing up faculty librarians to pursue other pressing priorities. The Valley Library at Oregon State University has relied entirely on part-time professional librarians to cover reference desk shifts since fall 2009, relieving faculty librarians of this task. Faculty continue to provide desk backup, chat reference, and research consultation.

In 2012, the authors invited both the part-time and faculty librarians to participate in a study, using a separate survey for each group, to elicit their experiences and impressions of the model. The goal was to determine the model's effectiveness and to identify changes that might be needed to improve it. Participants concluded that the model works well, although faculty feel they may be underinformed on important research and instruction issues brought up by students in their departments. They believe that some improvements to the referral process should be investigated. A follow-up assessment of patron satisfaction is indicated before a full picture can be developed on the success of this model.

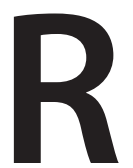
eference service needs at academic institutions have dramatically evolved over the last few decades. The nature of student and faculty reference requirements has changed. These changes can be attributed in part to technological advances and online search mechanism improvements. There is also increased demand for academic librarians to reshape their instruction programs to maximize their impact in the context of campus realignment. Academic librarians must spend more time providing assistance with in-depth research, data management, scholarly communication, and information literacy training, among many other things. ${ }^{1}$ Driven by these pressures, academic libraries are continuously challenged to find a new model that can adequately provide for the continuing immediate reference needs of their students and faculty while still addressing all these other demands.

As activities at reference desks decrease, change, and evolve, libraries are experimenting with nontraditional ways of staffing the desk and providing reference services in an effort to find something that works best for their particular situation. Much of this activity is due to a distinct change in the type of questions asked, shifting increasingly from ready reference and subject specialty queries to technical and directional requests. ${ }^{2}$ Many libraries are replacing full-time faculty librarians 
at reference desks with paraprofessionals, student workers, on-call librarians, or a combination of these. ${ }^{3}$ While some libraries are moving from a single desk model to having two or more service desks in proximity, ${ }^{4}$ others are merging service points to eliminate separate reference desks entirely. ${ }^{5}$

In a 2010 article, Middleton reviewed the reference needs and services at the Valley Library, the main campus branch of the Oregon State University (OSU) Libraries. ${ }^{6}$ Between 2003 and 2008, the number of traditional reference questions at the desk decreased by 50 percent. At the same time, faculty librarians were increasingly called upon to become more active in professional and university activities and to provide more academic support through information literacy education, individual research consultations, digital content management, and creation of new instructional tools.

In addition to the library's instruction program, the Teaching and Engagement Department at the Valley Library is responsible for operations at the Information Desk (which includes reference service) and in the Learning Commons. Since tenure-track faculty librarians typically filled the primary staffing role at the Information Desk, the department determined that here would be an obvious place to gain the additional hours necessary to allow their faculty to concentrate on other priorities. To reduce faculty librarian hours on the desk, the library hired a pool of seven part-time reference librarians (PTLs) to assist with desk coverage. By the fall of 2009, the library had increased this part-time pool to cover all eighty-one hours per week that had previously been covered by faculty librarians; faculty librarian involvement in desk reference has transformed into backup for the desk staff. To determine if the new arrangement was working effectively, a faculty librarian and a part-time reference librarian developed a survey to address several questions with each group concerning the effectiveness of training, communication, and referral, as well as to ask for suggestions to improve the arrangement. ${ }^{7}$

\section{LITERATURE REVIEW}

Library literature discusses a variety of nontraditional reference desk staffing models. Zabel discussed several of these. ${ }^{8}$ Some libraries use a tiered model with paraprofessional library staff and students serving at the desk, referring reference questions to full-time faculty librarians. Another trend has been to combine the reference and circulation desks into a single service point for patrons. Other libraries recruit staff or librarians from other areas of the library, such as technical services or information technology, to assist at the reference desk. Some libraries have tried different models but then returned to the traditional one with professional librarians staffing the desk, assisted by other library staff and student workers. One reason given for switching back to this librarian-staffed model was that librarians missed being on the desk.

Zabel sees the decline in the number of reference questions as one driving force in the reduction of professional staff at reference desks. ${ }^{9}$ Service Trends in ARL Libraries,
1991-2012 shows this trend continuing with a 69 percent decrease in reference questions since 1991, even though the total number of questions of all kinds is still substantial. ${ }^{10} \mathrm{In}$ her investigation of the cost-effectiveness of traditional academic library reference desk staffing, Ryan concluded that 89 percent of questions asked could be answered by nonlibrarians. ${ }^{11}$ No longer is it cost-effective to have a highly-trained subject specialist sitting at a desk waiting for the rare occasions when her expertise is actually needed, only to answer directional and technical (computer and printer) questions. In their 2008 random survey of 191 academic librarians in the United States, Banks and Pracht found that 60 percent of their respondents indicated that while the total number of reference desk staff remained the same, many libraries were using non-MLS personnel at their reference desks because "they were more cost effective and freed up MLS personnel for other responsibilities."12

Zabel observes that, although the total number of reference questions has gone down, their complexity has increased; she and her colleagues have seen this trend among their business library patrons. Chow and Croxton, among others, note that academic library patrons still have need for immediately available research-related assistance, along with a preference for receiving in-person assistance from a professional. ${ }^{13}$

A possible solution considered by some libraries is to staff the reference desk with professional, part-time librarians. This model, from an institution's point of view, has many benefits. It can be a cost effective solution, saving on salaries and benefits. ${ }^{14}$ The size of the librarian pool and the number of desk hours covered can more easily be adjusted to budgetary fluctuations and the ebb-and-flow of student needs during the school year. But as Wu points out, there may be problems inherent in hiring part-time reference specialists as library staff. ${ }^{15}$ These issues include high turnover, lack of training, lack of interest in academic libraries, and the burden of other responsibilities such as other jobs, classes, and family. Although the staff members Wu describes in her article are library science graduate students and not yet degreed professionals, the problems are similar when using degreed librarians in a part-time capacity. Since most of these advantages and disadvantages were pointed out in the much earlier article by Chervinko, ${ }^{16}$ it appears that little has changed over the decades, and library administrations will continue to deal with these issues.

From the point of view of the part-time professional, the arrangement is a combination of positive and negative elements. Wamsley describes advantages and disadvantages of working as a part-timer in her 2008 OLA Quarterly article, "The Adventures of a Part-Time Librarian."17 She likes the advantage of flexible schedules that allow for more family time and outside interests. She also notes that part-time librarians with several jobs have the opportunity to test out different environments, developing skill sets from varying types of libraries and patrons. These environments can also create networking opportunities with a wider group of library colleagues. Obvious disadvantages include fewer (or no) benefits, uncertainty of scheduled hours, and the 


\section{FEATURE}

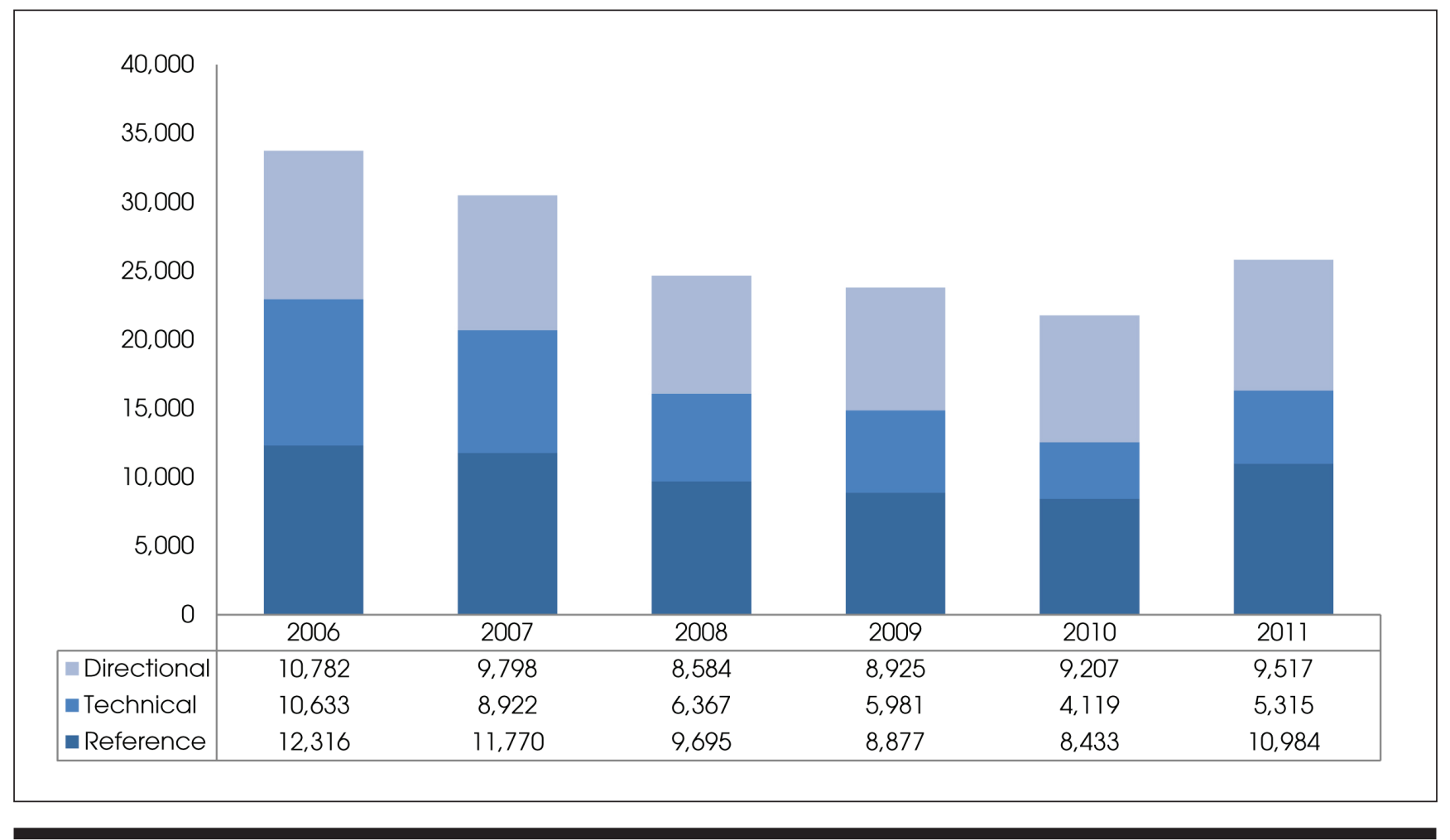

Figure 1. Types of OSU Valley Library Information Desk Questions 2006-11

disconnectedness an employee can feel when not at an organization in a full-time capacity.

\section{THE OSU VALLEY LIBRARY MODEL}

The Valley Library at Oregon State University previously operated on the traditional academic library model, with a subject-specialist faculty librarian staffing the reference desk for a shift of two to four hours supported by a trained student worker. However just like the libraries in the ARL statistics, the Valley Library has seen a significant drop-off in the number of reference questions asked over the years. Figure 1 shows that from 2006 to 2010, the total number of all types of questions received (including technical and directional) fell 38 percent. The number of reference questions overall for 2006 to 2010 decreased by 32 percent. Technical assistance questions dropped drastically in 2008 with the addition of a computer help desk, while directional questions held fairly steady. ${ }^{18}$

The reference statistics tracked included all formats for asking reference questions that are available at the Valley Library: in-person, chat, text, and e-mail. To parse this out, chat reference use grew steadily from its adoption in 2003 but has been falling since 2007. E-mail reference has also dropped sharply (see figure 2).

The decline in desk statistics was not the only reason that the Valley Library determined it could no longer support traditional desk staffing. As outlined by Middleton, ${ }^{19}$ budget decreases and shifting priorities were reducing the number of subject specialist faculty librarians available for reference work. At the same time, other faculty duties demanded an increasing amount of time and attention, including promoting information literacy and developing online tools and services. The Valley Library began to look for a way to continue serving all their patron needs while changing how they staffed the reference desk. As Middleton describes it, the library first reduced the number of faculty librarians covering desk hours from ten librarians to seven librarians and reduced the total number of hours for each librarian to four per week. ${ }^{20}$ The remaining hours were covered by trained part-time reference specialists. These specialists, which started out as on-call librarians who "filled in" on an irregular basis when needed, were thus transformed into a group of part-time librarians (PTLs) with an expanded and more regular schedule and broader training. Eventually the faculty librarians were taken off regular desk shifts altogether. This allowed them to concentrate on their other duties and projects.

Deciding to move faculty librarians off the reference desk caused some concern among a number of them about losing touch with needs of students. They were previously able to discern some of these needs through the regular, in-person contact at the service desk. In an effort to retain some of that connection, faculty librarians agreed to serve as a backup to the desk service and perform regular chat reference shifts from their own desks. A referral process was established to forward subject-specific and more in-depth research questions to the faculty librarians, with an expectation that this 


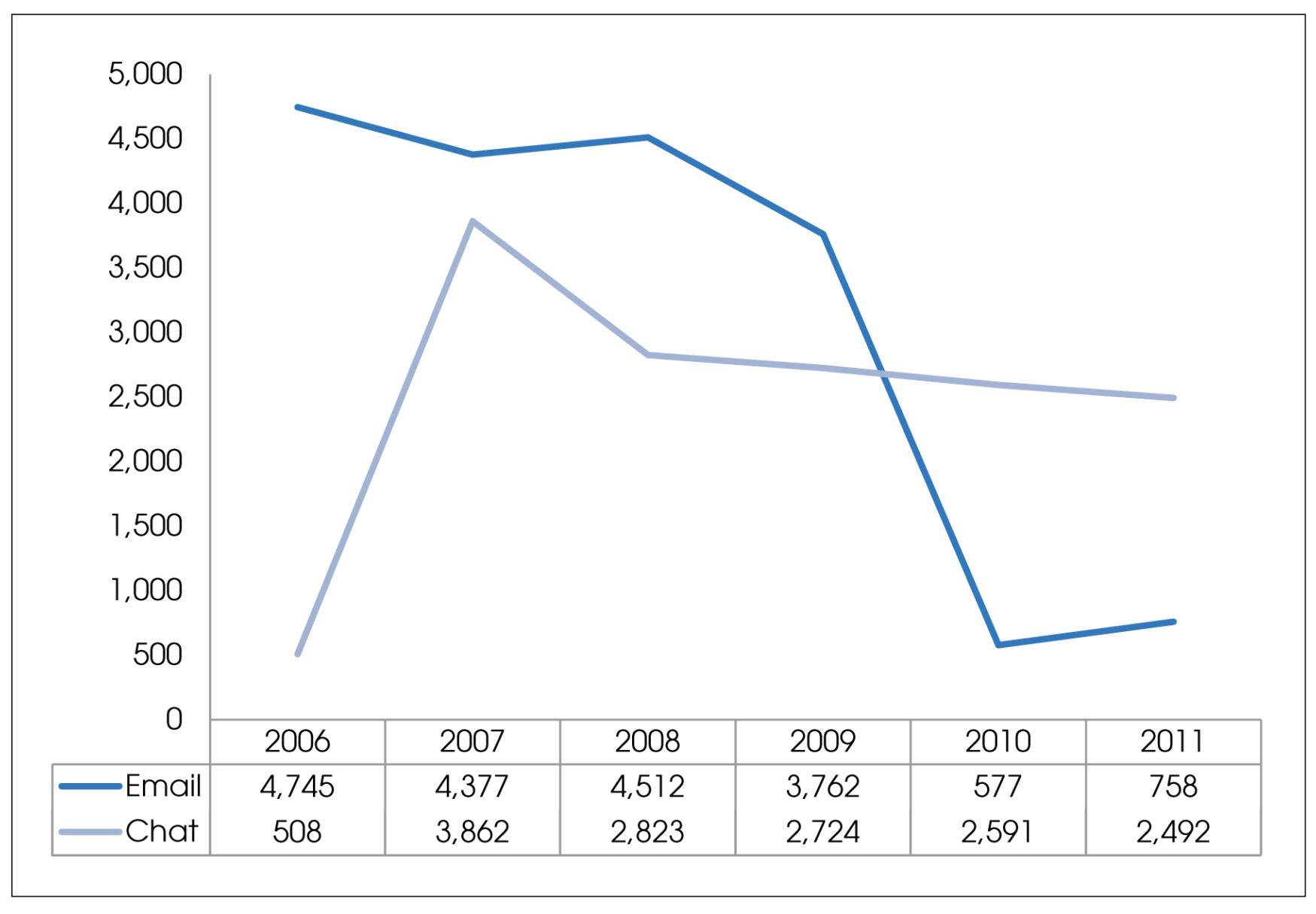

Figure 2. E-mail and Chat Reference Questions 2006-11

also would serve to keep them in touch with student needs.

The PTLs hired to serve as reference specialists and replace the faculty librarians at the desk are considered temporary employees. University policy dictates that they can work no more than eighty-nine days per calendar year. They typically work several three- or four-hour shifts per week depending on their availability. These shifts include evening and weekend hours, allowing about sixty hours per week of desk coverage during the school year. Although they do not receive typical employee benefits, PTLs are included in employee in-service days and other in-house professional development activities arranged by the library. Staffing the desk with part-time librarians also provides for some backup of student workers on the desk as well as providing professional reference assistance to the patrons.

While the PTLs are not required to have any subject expertise, they are (with rare exceptions) credentialed librarians. They generally do not perform the other duties of faculty librarians, although some may teach library sessions to freshman writing classes. Their primary role is to provide reference assistance at the information desk (the new designation for the reference desk).

People hired as PTLs at the Valley Library are a mix of new librarians seeking work experience along with experienced librarians wanting to have a reduced and more flexible workload. Several of the latter are retired librarians supplementing their retirement income. The PTLs and the student workers on the desk are supervised by the Learning Commons coordinator, a librarian with professional faculty status (i.e., nontenured). She is backed up at night by the evening desk manager, who is a library paraprofessional. The Learning Commons coordinator and the evening desk manager often fill in for PTLs and student workers who are out, as do the faculty librarians who also provide question referral support and desk backup as needed.

The Learning Commons coordinator primarily provides the training, supplemented by some of the faculty librarians. Online tutorials and an extensive online reference desk manual support the in-person training. New PTLs "shadow" more experienced PTLs for several weeks before being scheduled as the only librarian on the desk. They always have one student worker scheduled with them.

\section{METHOD}

There were several purposes to the study. First, the study sought to determine if the current approach to reference desk 


\section{FEATURE}

staffing is fulfilling the needs of the library to have professional high-level reference assistance readily available to the patrons. Second, the study sought to discover if the parttime librarians (PTLs) feel they are receiving sufficient and appropriate training and support to be effective. The third purpose was to ascertain if the faculty librarians who had been relieved of desk staffing duties found the new arrangement a satisfactory replacement for their direct involvement in face-to-face reference. The investigation consisted of an anonymous survey consisting of a mix of multiple choice and open text questions to review current practice and attitudes of PTLs on the information desk. Another similar survey was given to the faculty librarians who provide backup to the PTLs (see appendix). Also included was a review of Valley Library reference statistics. Because of the small number of people in the study, a mix of both quantitative and qualitative survey questions was judged to be the best approach to get a more complete picture. Also due to the necessarily small sample size, the conclusions of this study may not be generally applicable.

The PTL questions covered training, communication, and the sufficiency of the tools provided. For the faculty librarians, questions concerned the impact of the chat and backup duty requirement on their other work and how often they were called upon to back up the desk. Both groups were asked about their perception of the effectiveness of the referral process. This process provides for questions that cannot be answered by the PTL or the student at the desk, allowing a referral to a faculty librarian through a variety of means (an online form, chat, e-mail, or phone). The survey also invited recommendations for improvements the respondents would like to see.

Following institutional review board approval, the members of each of the two subject groups received an e-mail invitation to participate in the study, followed a week later with a reminder and a final reminder the day before the survey was due. Study investigators used the Qualtrics survey software, allowing them to quantify the answers to the multiple choice questions while protecting the anonymity of the participants. The study investigators began analyzing the results as soon as the surveys closed. Surveying patron satisfaction was not planned as part of this study.

\section{SURVEY RESULTS AND INDICATIONS}

Both surveys were administered late July through mid-August, 2012. At the time of the survey nine faculty librarians covered chat reference and served as backup for the parttime librarians at the desk; the survey for this group had 100 percent return. The part-time librarian (PTL) survey was sent to fourteen librarians who either worked currently at OSU or had worked at OSU within the previous twelve months; twelve $(85.7 \%)$ responses were returned.

\section{PART-TIME LIBRARIAN SURVEY FINDINGS AND DISCUSSION}

PTLs collaborate with faculty librarians on patron questions in two ways: direct consultation, with the faculty librarian serving as backup, and referral. Because it is not directly captured in statistics, the survey asked about how frequently PTLs make contact with the backup librarian, either to ask questions or to cover for them at the desk, along with their level of satisfaction with the process. Only PTLs who work days were asked this question, since backup librarians are not available nights and weekends. Out of the eight total responses to this question, two of the PTLs indicated they used this option "frequently," but six of them said "rarely or never." The follow-up question about overall satisfaction with the support revealed that nobody was actively dissatisfied, but there was not a lot of enthusiasm either. Six indicated satisfaction but the rest were neutral.

Valley Library offers patrons and PTLs several avenues for referral to a faculty librarian: chat, phone, e-mail, and online referral form. PTLs reported using all the available contact methods but say that the least used was the referral form. However, statistics revealed that chat was actually the least often used method of referral. Whether this is due to a misperception or whether chat referral is too often unreported in the statistics is unclear.

Low reported use of the online referral form is a matter of some concern, since the form was designed to transfer questions to the reference e-mail box where the backup librarian on duty would either answer directly or forward it to the appropriate subject librarian. The form was meant to eliminate the undesirable situation of a referral sitting unanswered in the mailbox of a librarian who was out for several days due to conference, vacation, or illness. With all the faculty librarians located on a different floor than the information desk, the faculty librarian serving as backup would have a better idea of who was available than the PTL. But this still happens when referrals are made by phone, and a message is left if no librarian answers. At least some of the PTLs might prefer to directly contact specific subject librarians:

I would like to be able to flag the referral form for a particular subject librarian. The current process sends a referral to a joint reference e-mail inbox. In the past, when something has been subject specific I've sent an individual e-mail to a subject librarian, bypassing the referral form.

Often, however, PTLs may simply be forgetting that referral is an option:

Make referral to a subject librarian more intuitive or built into the workflow. Often I get so caught up in trying to answer a question, I forget about referrals as an option. 
Whether referrals are low because the reasons for using the online referral form have not been sufficiently communicated, or PTLs feel they are expected to answer everything on their own, or whether there is active resistance to using the form, the comments suggest that the library should look into adjusting or redesigning the referral system. Better training of PTLs in when it is appropriate to make referrals is also something which might improve the process as well as reminding them more often of the existence of this particular line of communication.

One response pointed to another possible explanation for the PTL resistance: a perceived distrust of the referral system by patrons. PTLs are encouraged to call the faculty librarian on backup duty or the specific subject expert if needed to answer a difficult question. But if this help is unavailable (evenings, weekends, and departmental meeting times for example) the PTL is supposed to refer the patron question via an online referral form. Patrons sometimes show unhappiness with this arrangement:

When we refer them [students] they so often react like we are just trying to be rid of them-casting them into a black hole. They do not believe that we are actually helping them, because they do not believe that the librarian will ever get back to them. One particularly frustrated patron was stunned that she was contacted while still in the library and that her appointment happened in less than an hour. Despite our reassurances she said [she] had felt sure that nothing would come of the referral. I probably refer less than (or less quickly than) I ought to for this reason-usually the already frustrated patrons that are already about to snap.

\section{FACULTY LIBRARIAN SURVEY FINDINGS AND DISCUSSION}

One of the most positive aspects of the desk staffing change is that faculty librarians have indeed gained time for pursuing other duties and priorities by being relieved of the "burden" of sitting at the reference desk. Because they monitor chat from their own desks, faculty librarians are often able to concentrate on other work during a shift. Of the nine faculty librarians surveyed, only one librarian indicated that she felt that being scheduled to answer chat and be available to back up the desk had much impact on other work. All other respondents reported some variation on "very little impact." More than half of the faculty felt that the weight of their chat and backup duties was light enough that they could book something else, such as meetings or research consultations, in addition (double-book) during that time. One librarian even reported doing so "frequently." Because chat is not very busy during particular hours of the day or certain weeks during the term, it is not uncommon to attend a meeting where a librarian has her laptop logged in and monitoring chat but is still able to fully participate in the meeting.
A follow-up conversation with the Learning Commons Coordinator revealed one reason why the reported impact of serving as the desk backup is so small: only a few shifts per week are lengthy enough for the PTL to require a break, and they are more likely to either wait for a slow period or to call upon the supervisor or the student workers to cover for them, relieving faculty backup librarians from this duty. When there is a PTL absence from a shift, the coordinator will often fill in or find another PTL to take the shift rather than call upon the faculty librarian to do so.

In the other direction, even though they know it is an option, every faculty respondent claimed to have never asked a PTL to cover chat for them when they were out. Instead, when they know in advance that they will be unable to fill their shift, they will trade hours with another faculty librarian. If their absence is on short notice (such as a sudden illness), coverage is often arranged via e-mail exchanges or provided by the desk supervisor instead.

Responses from the faculty librarians indicate there is some degree of concern about the model's effectiveness when it comes to the referral process (one librarian of the nine responding indicated disagreement that the process is effective and timely; four others neither agreed nor disagreed). As stated previously, one worry that many of the faculty had when the new staffing model was proposed was that they would become out-of-touch with what is going on with library assignments in classes being taught in their departments. Some faculty librarians report still feeling this way in the survey. Most have little interaction with the desk any more and are no longer seeing the assignment-related questions they formerly used as an indicator of needs in their subject departments:

I would like to be better informed as to what sorts of questions in my area are being asked (even [when] the PTL is able to provide a response). If I never receive this user input, I feel that I have a more difficult time providing instruction and selection services.

In addition to this desire to know what questions are asked in their subjects, a few of the faculty librarians want to receive more referrals, and some would like to return to the practice of having referrals sent directly to a specific subject librarian. This is certainly understandable: the backup librarian is more likely to answer a referred question herself whenever possible than to pass it to a subject specialist. There is also uncertainty about whether the library is meeting patron information needs and a perception that the referral process is not being utilized effectively: when asked if the referral process is working well, only four out of nine responders agree. The response is only somewhat more positive when asked if the process is used appropriately by the PTLs (five out of nine).

The comments revealed that several faculty librarians believe that some of the questions that they ought to be getting are not being referred to them. The previous responder continued: 


\section{FEATURE}

I receive virtually no referrals. While it is possible there are never any questions, I doubt this is the case.

There also is uncertainty about whether patron questions that faculty librarians receive directly are the result of a desk referral or whether the patron is finding the librarian through some other method (i.e., web subject guide page, instructor referral, or remembering the librarian from a class visit). Another librarian commented:

I am really unsure about how the referral process is working, because I don't know how often PTI's refer, nor do users always tell me they were referred by the desk. I'm unsure if the referral process is working at all outside of the immediate referral of chat questions.

\section{NEXT STEPS}

While there is overall satisfaction with the new model, faculty and PTL groups both offered thoughtful suggestions for changes and improvements. One of these suggestions is to change the status of the PTLs from hourly part-time workers to regular salaried employees. Not only would this be more attractive to potential information desk staff, but many believe that this status change would create a stronger commitment to the library and university, and the library would be able to retain good people for longer periods. This change would, in many ways, compensate for several of the drawbacks outlined in Wamsley's article. ${ }^{21}$ While current economic realities of the library and university make this unlikely, at least at present, it is a recommendation that continues to come up.

Review of the responses in both surveys indicated that the most immediate need is for improved referral and communication. When one in four PTLs feel they are not being adequately kept "in the loop" on library policy changes, and faculty librarians report that they feel, in the words of one librarian, "out of touch with what is happening in the building and on campus," the library needs to address how to improve communication strategies.

One of the library faculty's biggest concerns when developing this model for the desk was that questions needing a subject specialist's attention be referred appropriately and speedily. Referral statistics are unavailable prior to 2010, and the count since then is incomplete, but records from January to December 2012 show only 664 of the 6,645 questions counted at the desk (10\%) are reported as being referred. Of these, most are referred to other departments within the library (most often the circulation and computer help desks); only $398(6 \%)$ of total referrals are made to subject librarians.

These statistics tend to support the feeling indicated in the library faculty survey that they are not being included on questions that they need to be involved in answering. Several possible approaches to improve this situation are under discussion, including better training of both PTLs and faculty librarians in the use of the referral form, increased emphasis during training on the reasons behind why the referral process was set up to submit questions to a general e-mail, and redesigning the form to allow copying a specific faculty librarian as an "FYI" in order to increase awareness of what kinds of questions are coming in their subject areas.

Anecdotal evidence from PTLs in their survey answers reveals that, despite a promised twenty-four-hour response, some patrons believe that a referral is a "dead end." A patron survey would be useful in discovering how prevalent this feeling is so that the library could find ways to address this perception. Various barriers exist that make implementing a user satisfaction survey difficult; survey fatigue is a real concern on campus. To prevent this, ongoing assessment strategies that transcend multiple surveys are being developed. This may enable libraries to determine if the changes they are making are effective and add to patron satisfaction with library services.

\section{CONCLUSION}

There are many different service models an academic library could adopt to deliver reference services, and each library must determine what is most successful for their own particular situation. They will need to continue to consider new ways of providing quality reference service and not be afraid to experiment. While this current model of service is working with a significant degree of success for the OSU Valley Library, it is highly unlikely that it will be the final model. Once the job prospects for librarians improve with the economy, for example, OSU and other libraries using a similar system that depends on on-call or part-time librarian reference coverage may find it difficult to find enough skilled professionals willing to work part time. As more library services transform into self-service (material checkout, ILL, placing and picking up holds, and so on) and budgets continue to shrink and shift to other priorities, ways of combining service points to provide quality service with fewer staff continue to be considered and tested. The public desire for quick, seamless, and efficient service received at as few locations as possible is driving OSU and others toward a "one-stop" model where more library services combine at a single desk. This summer, student computer and multimedia help services, which have for several years been available adjacent to the information desk, were moved to combine with the circulation desk. It is important for the library to measure what effect this loss of proximity has on questions received at the information desk and on the quality of services received at all access points and make changes as appropriate.

Only one thing is certain: libraries, including the Valley Library, will continue to change and adjust to fulfill their commitment to providing the best possible service to their users.

\section{References and Notes}

1. Janice M. Jaguszewski and Karen Williams, New Roles for New Times: Transforming Liaison Roles in Research Libraries (Washington, DC: Association of Research Libraries, 2013). 
2. Steven J. Bell, "Technology Killed the Reference Desk Librarian," Reference Librarian 48, no. 1 (March 1, 2007): 105-7, http:// dx.doi.org/10.1300/J120v48n99_09.

3. Julie Banks and Carl Pracht, "Reference Desk Staffing Trends," Reference \& User Services Quarterly 48, no. 1 (2008): 54-59.

4. Kimberley L. Bugg and Rosaline Y. Odom, "Extreme Makeover Reference Edition: Restructuring Reference Services at the Robert W. Woodruff Library, Atlanta University Center," Reference Librarian 50, no. 2 (March 31, 2009): 193-204, http://dx.doi .org/10.1080/02763870902755932.

5. Theresa S. Arndt, "Reference Service Without the Desk," Reference Services Review 38, no. 1 (2010): 71-80, http://dx.doi .org/10.1108/00907321011020734.

6. Cheryl Middleton, "From an Information Commons to a Learning Commons: Twelve Years of Change and Innovation at the OSU Valley Library," OLA Quarterly 16, no. 2 (Summer 2010): 7-12, http://dx.doi.org/10.7710/1093-7374.1280.

7. OSU Librarians have a twelve-month faculty appointment, are required to have a masters degree in library and information science, and must go through the promotion and tenure process. Part-time librarians (PTLs) are currently hired as temporary part-time employees with the required qualifications of either a master's degree in library and information science (preferred) or a bachelor's degree in any subject plus a minimum 1-year experience at a library information or reference desk.

8. Diane Zabel, "Trends in Reference and Public Services Librarianship and the Role of RUSA Part One," Reference \& User Services Quarterly 45, no. 1 (2005): 7-10.

9. Ibid

10. Association of Research Libraries, "ARL Statistics: Service Trends in ARL Libraries, 1991-2012”(2013), www.arl.org/storage/documents/ web-t1.xls.

11. Susan M. Ryan, "Reference Transactions Analysis: The CostEffectiveness of Staffing a Traditional Academic Reference Desk,"
Journal of Academic Librarianship 34, no. 5 (September 2008): 389-99, http://dx.doi.org/10.1016/j.acalib.2008.06.002.

12. Banks and Pracht, "Reference Desk Staffing Trends."

13. Anthony S. Chow and Rebecca A. Croxton, "Information-Seeking Behavior and Reference Medium Preferences," Reference \& User Services Quarterly 51, no. 3 (2012): 246-62; Joel Cummings, Lara Cummings, and Linda Frederiksen, "User Preferences in Reference Services: Virtual Reference and Academic Libraries," portal: Libraries and the Academy 7, no. 1 (2007): 81-96, http:// dx.doi.org/10.1353/pla.2007.0004; Diane Granfield and Mark Robertson, "Preference for Reference: New Options and Choices for Academic Library Users," Reference \& User Services Quarterly 48, no. 1 (2008): 44-53

14. James S. Chervinko, "Temporary Employees in Academic and Research Libraries," Journal of Academic Librarianship 12, no. 4 (September 1986): 217; Ryan, "Reference Transactions Analysis."

15. Q. (Kerry) Wu, "Win-Win Strategy for the Employment of Reference Graduate Assistants in Academic Libraries," Reference Services Review 31, no. 2 (2003): 141-53, http://dx.doi .org/10.1108/00907320310476611.

16. Chervinko, "Temporary Employees in Academic and Research Libraries."

17. Lori H. Wamsley, "The Adventures of a Part-Time Librarian," OLA Quarterly 14, no. 3 (Fall 2008): 5-7, http://dx.doi. org/10.7710/1093-7374.1206.

18. Figure 1 also shows that reference questions started to increase again in 2011. With only one year to compare, this cannot yet be identified as a trend. It may simply be due to increased university enrollment (up 8.2\% in 2009-10 and 5.1\% in 2010-11).

19. Middleton, "From an Information Commons to a Learning Commons."

20. Ibid.

21. Wamsley, "The Adventures of a Part-Time Librarian."

\section{APPENDIX. SURVEY QUESTIONS}

\section{PTL Model: Faculty Survey}

\section{EXPLANATION OF FACULTY LIBRARIAN ROLE}

As a faculty/subject librarian at OSU Libraries, you have scheduled shifts covering the chat service and, simultaneously, serve as backup librarian for the information desk. In this role you cover PTL breaks and absences when needed and answer questions referred to you from the desk. The following questions cover your experiences in your role as the backup librarian.

How many times, during a typical quarter, are you required to cover an information desk shift (ie, no PTL available)? Never (0) _ Rarely (1) _ Sometimes (2-3)_ Often (>3)

Have you ever scheduled yourself for meetings or some other task that takes you away from your desk during your chat/ backup shift ("double-book")?

Never___ Once or twice Sometimes__ Frequently

If Never is selected, then skip the next question

When you have double-booked, did you ask the PTL to cover your chat duties for you?

_ No _ Yes, sometimes_ Y Yes, usually

In what ways does serving as back-up to the part time librarians impact your work?

If you could change something about the current information desk model, what would it be? 


\section{FEATURE}

\section{REFERRAL PROCESS}

OSU Libraries uses a tiered reference referral process. Questions that cannot be answered by the PTL or the student at the desk are referred to a faculty librarian. This section deals with the question referral process. Please indicate if you agree or disagree (and to what extent) with the following statements.

Overall the referral process works well.

__ Strongly Agree _ _ Agree _ Neither Agree nor Disagree _ _ Disagree _ _ Strongly Disagree

The referral process is used appropriately by PTLs.

_ _ Strongly Agree _ _ Agree _ Neither Agree nor Disagree _ _ Disagree _ _ Strongly Disagree

The referral process is effective and timely enough that I believe it sufficiently meets patron needs.

_ _ Strongly Agree _ _ Agree _ _ Neither Agree nor Disagree _ _ Disagree _ _ Strongly Disagree

If you could make changes to the referral process what would they be?

Please share any other comments you may have about the PTL model and/or the referral process at OSU Libraries below:

\section{PTL Model: PTL Survey Questions}

\section{TRAINING}

Please give us your opinion on each of the following statements.

The Library provides its PTLs (part time librarians) with sufficient training to effectively answer the types of questions asked at the information desk.

_ Strongly Agree __ Agree _ _ Neither Agree nor Disagree _ _ Disagree _ _ Strongly Disagree

As a part-time employee, you are kept adequately informed of changes to library policies and procedures.

_ _ Strongly Agree _ _ Agree _ Neither Agree nor Disagree _ _ Disagree _ _ Strongly Disagree

How would you MOST prefer to be kept informed of changes to library policies and procedures? (Choose one)

by individual e-mail __ verbally by supervisor notebook at the desk by e-mail to RefSub mailbox other (please tell us how)

\section{BACKUP LIBRARIAN}

A faculty librarian is scheduled as backup support for the part-time librarian weekdays from $10 \mathrm{am}-5 \mathrm{pm}$.

[PTLs who normally only work evenings and weekends were not asked this question since they are unlikely to have contact with backup librarians]

How often, during a typical quarter, do you consult a backup librarian? (The method does not matter-it could be in person, or by phone, e-mail, or chat.)

_ Never _ Rarely (1 or 2 times) _ Occasionally (3 or 4 times) _ _ Frequently ( $>4$ times)

Please rate this statement: Overall I am satisfied with the support offered by the backup librarian during my desk shift.

_ Agree _ _ Neither Agree nor Disagree _ _ Disagree 
REFERRAL PROCESS

OSU Libraries uses a tiered reference referral process. Questions that cannot be answered at the desk are referred by a variety of means to a faculty librarian.

Please rank these referral methods by how often you find them useful ( $1=$ used most often to $4=$ used least often).

_Chat__ Phone _E-mail _ Online referral form

If you could change something about the current referral process, what would it be?

\section{TOOLS}

I feel that I am provided with the tools I need to effectively answer questions at the information desk. 